Studia nad Autorytaryzmem i Totalitaryzmem 43, nr 2

Wrocław 2021

https://doi.org/10.19195/2300-7249.43.2.11

\author{
ANDRZEJ BATOR \\ ORCID: 0000-0003-4772-7920 \\ Uniwersytet Wrocławski \\ andrzej.bator@uwr.edu.pl
}

\title{
Dogmatyka prawa wobec politycznej opresji. Czy historia myśli prawnej może nas czegoś nauczyć?
}

\begin{abstract}
Slowa kluczowe: europejska kultura prawna, paradygmat dogmatyki prawa, polityczność prawa, rewolucja w prawie, niemiecka szkoła historyczna.
\end{abstract}

\section{DOGMATICS OF LAW IN THE FACE OF POLITICAL OPPRESSION: CAN THE HISTORY OF LEGAL THOUGHT TEACH US ANYTHING?}

\begin{abstract}
One of the contemporary views formulated and popularized mainly by authors from the socalled critical theory of law is the belief in the inevitable, mutual relationship of law (theory of law and dogmatics of law) and legal practice (adjudication) with politics and the political. This position is strengthened by the observation of contemporary disputes - especially visible in Poland — with the participation of politicians and lawyers: politicians accuse lawyers of political motivation of actions taken to defend the judiciary and the rule of law, while lawyers defend themselves by arguing the need for autonomy of their professional practice, including its apolitical nature. In this text, I explain the arguments of the latter party to the dispute. I choose the dogmatics of law as the field of illustrating the issues raised, since it occupies a special place in the continental legal scholarship, acting as an intermediary between the jurisprudence and legal decision-making practice. I am trying to show - by referring to two examples from general history, i.e. the eleventh-century investiture controversy and the nineteenth-century debate in the background of the German reunification idea - that law and politics (lawyers and politicians) have always been forced to compete and cooperate with each other. Thus, it confirms the thesis of the critical theory of law. At the same time, however, I try to show that the legal community had the ability to "learn" from the political disputes of the past, which led to the formation of independent jurisprudence and legal practice in the face of current politics, and thus also to apoliticality. What is more, I argue that such an apolitical nature is a condition for the survival of legal culture in its present shape - and here, my path diverges from the critical legal theory claims. However, in my opinion, the contemporary arguments made
\end{abstract}


within this theory about the political science of law and jurisprudence should be treated with all seriousness - as another experience from which our community, as one can hope, will be able to draw informative conclusions.

Keywords: European legal culture, the paradigm of dogmatics of law, the political nature of law, revolution in law, German historical school of jurisprudence.

\section{1.}

W kontynentalnej kulturze prawa stanowionego dogmatyka prawa zajmuje miejsce szczególne. Nie tylko dominuje nad pozostałymi dyscyplinami prawoznawstwa swoim dorobkiem naukowym, organizacyjnym gruntowaniem oraz zasobami kadr badaczy, ale również ma najdalej idący wpływ na zawodową praktykę prawniczą, przede wszystkim sędziowską. Z kolei poprzez swoje powiązania z analityczną teorią prawa (zbieżność zainteresowań obejmujących zagadnienia języka prawnego) znajduje badawcze wsparcie w osiągnięciach tejże teorii — równie mocno powiązanej z kulturą prawa stanowionego i intensywnie rozwijanej, co przez dziesięciolecia widoczne było także w polskiej ogólnej nauce prawa. Wszystko to razem kształtuje przekonanie, że współczesna refleksja dogmatycznoprawna wykształciła względnie autonomiczny status oparty na własnym paradygmacie badawczym (zestawie utrwalonych, quasi-aksjomatycznych założeń, twierdzeń oraz reguł i procedur) pozwalającym na rozwiązywanie standardowych problemów badawczych - a w konsekwencji również problemów praktycznych. Profesorowie prawa cywilnego, prawa karnego czy prawa pracy oraz sędziowie orzekający $w$ tych wyspecjalizowanych obszarach reprezentują dzięki temu $\mathrm{w}$ miarę jednorodną, sprofesjonalizowaną oraz zautonomizowaną wobec otoczenia społecznego grupę ,prawników”. Łączy ich wiele: przedmiot analiz (język tekstów prawnych), podobny typ stawianych pytań (kwestie walidacyjne, interpretacyjne), sposób argumentacji w spornych kwestiach (środowiskowo podzielany zestaw pojęć, rozliczne „prawnicze” rozumowania, maksymy, topiki itp.). Łączy ich również uniwersytet z wydziałami prawa realizującymi podobne programy nauczania - uniwersytet, który kiedyś ukończyli lub przy którym trwają całe swoje życie zawodowe.

W kulturze prawa stanowionego środowisko prawnicze wiąże jednak coś jeszcze, mianowicie wartości, które w prawie znajduje lub których spełniania od prawa (prawodawcy, organów stosowania prawa) oczekuje. Mogą to być uniwersalne wartości (tak zwane wewnętrzne wartości prawa) artykułowane w ramach zasady praworządności, akceptowanej zarówno przez kontynentalną (doktryna Rechtsstaat), jak i anglosaską (koncepcja Rule of Law) kulturę prawną. Mogą to być także wartości o zasięgu bardziej lokalnym, na przykład — gdy chodzi o polską kulturę prawną — normatywne przekonania (lokowane w tak zwanej głębokiej strukturze prawa) 
składające się na założenie o racjonalności prawodawcy ${ }^{1}$. Oba przykłady łączy to, że jakkolwiek są bardzo istotne w decyzyjnej praktyce prawniczej, to wypracowane zostały przez doktrynę, głównie przez naukę prawa. Tego rodzaju zautonomizowane standardy/wartości sprzyjają separowaniu aktywności prawników wobec bieżącej polityki. Poprzez ich „wewnętrzny” lub ,głęboki” status w strukturze prawa i naukową proweniencję nabierają cech apolityczności. Środowisku akademickiemu legitymizacji do autonomii dostarcza pozytywizm prawniczy z jego scjentystycznymi inklinacjami badawczymi, opartymi na metodologicznych założeniach pozytywizmu naukowego (prawda, obiektywizm, badawcza specjalizacja). Autonomię środowiska sędziów ugruntowuje z kolei zasada trójpodziału władz (bezstronność, niezawisłość, zawodowa specjalizacja). Jednych i drugich łączy apolityczność. Jednak z racji na kierunek odziaływania wypracowanych przez doktrynę prawniczą zasad i wartości - prowadzący do ograniczania rzeczywistej władzy prawodawcy — te standardy i sędziowskie decyzje na nich oparte uzyskują walor działań politycznych. Prawniczy paradoks polityczności? Moim zdaniem nie, a jeżeli już, to pozorny.

W niniejszym tekście będę próbował argumentować, że nie tylko mamy tu do czynienia z dylematem pozornym, ale również że napięcie między neutralnością światopoglądową i politycznością kumuluje w sobie siłę stymulującą rozwój teorii prawa, dogmatyki oraz zawodowej praktyki prawniczej. Sięgając do pewnych historycznych źródeł nowoczesnego prawoznawstwa, zamierzam pokazać, że nauka prawa zbudowana na tradycji civil law oraz ukształtowana na jej zrębach aktywność prawników wyrosły z konfliktów politycznych, a następnie zmuszone były z polityką stale, choć okazjonalnie (nie wszystko przecież w życiu społecznym jest „polityczne”) kooperować. Ta współpraca budowała zdolność do rozwiązywania przyszłych konfliktów politycznych. Aby jednak znawcy prawa mogli skutecznie tę rolę wypełniać, powinni kierować się utrwalonymi w kulturze prawnej zasadami i wartościami budującymi ich zawodową (naukową, decyzyjną) autonomię.

\section{2.}

Historia prawa dostarcza nam dwóch „opowieści” o tym, jak powstało i jakie czynniki zrodziły europejskie — a ściślej, kontynentalne — prawoznawstwo $\mathrm{z}$ dogmatyką prawa $\mathrm{w}$ jego centrum ${ }^{2}$. Zacznijmy od starszej $\mathrm{z}$ nich, sięgającej

${ }^{1}$ O szczególnej pozycji w polskiej kulturze prawnej konceptu racjonalności prawodawcy piszą między innymi: M. Zieliński, Wyktadnia prawa. Zasady. Reguty. Wskazówki, Warszawa 2002, s. 277; L. Nowak, Spór o definicje legalne a sposób „pojmowania prawodawcy”, „Państwo i Prawo” 1969, nr 3, s. 514; Z. Ziembiński, Problemy podstawowe prawoznawstwa, Warszawa 1980, s. 25; M. Zirk-Sadowski, Prawo a uczestniczenie w kulturze, Łódź 1998, s. 92; P. Kantor-Kozdrowicki, Racjonalność prawodawcy jako paradygmat nauk prawnych, „Folia Iuridica Universitatis Wratislaviensis” 8, 2018, nr 1, s. 95 n.

${ }^{2} \mathrm{~W}$ tradycji anglosaskiej termin „dogmatyka prawa” występuje dość sporadycznie i raczej jest tam odbiciem myśli kontynentalnej. Doświadczyłem tego niedawno przy okazji recenzowania 
wczesnego średniowiecza (XI wiek). Otóż zdaniem pewnej grupy wpływowych historyków to nie rewolucja francuska i ekspansja filozoficznej myśli oświecenia okazały się punktem zwrotnym w prawnej historii Europy, lecz znacznie starszy od tych zdarzeń polityczny konflikt o inwestyturę. Niemiecki historyk prawa Gerd Tellenbach ujął to w taki oto sposób: „ruch, mający na celu wyzwolenie Kościoła spod królewskiej [...] kontroli — którego początek datuje się na 1058 rok — był wielką rewolucją w dziejach świata, a papież Grzegorz VII wyznaczył jedyny być może $\mathrm{z}$ duchowej perspektywy punkt zwrotny w historii katolicyzmu [...]". Jak dodaje Tellenbach, papież był „do głębi rewolucjonistą" ". Pogląd ten rozwija również Richard W. Southern, stwierdzając, że w konsekwencji tego konfliktu ,świeccy władcy pozbawieni zostali swojego swego quasi-sakralnego splendoru, a papież uzyskał nowe możliwości interweniowania i kierowania zarówno życiem duchowym, jak i świeckim [...]. To właśnie wtedy „ekspansja Europy zaczęła się na dobre”4.

Dla prawoznawstwa konsekwencje tych znanych z historii powszechnej wydarzeń wyprowadza Harold J. Berman w znanej także polskiemu czytelnikowi monografii Law and Revolution. The Formation of the Western Legal Tradition (Harvard 1983) $)^{5}$. Berman jest autorem, który w sposób wyjątkowo wnikliwy, na ponad 600 stronach, udokumentował wpływ przywołanego wyżej konfliktu politycznego (konfliktu o władzę) na znany nam do dzisiaj kształt europejskiej kultury prawnej. Jak pisze:

wraz z rewolucją papieską powstaje klasa profesjonalnych prawników i sędziów, hierarchiczna struktura sądów, szkoły prawa [...] oraz samo pojęcie prawa jako niezależnego, zintegrowanego i rozwijającego się zespołu zasad i procedur”. W następstwie tych wydarzeń „,wyłonił się nowy system prawa kanonicznego oraz nowe systemy prawa świeckiego [...]. Systematyzacja i racjonalizacja prawa niezbędne były dla utrzymania równowagi między licznymi współzawodniczącymi systemami. Słuszny porządek rzeczy wprowadzony przez rewolucję papieską $[\ldots]$ pozwolił na pogodzenie skonfliktowanych władz na gruncie syntetyzujących

mojego tekstu (z tym właśnie pojęciem w „roli głównej”) przez recenzenta jednego z brytyjskich uniwersytetów. Ów recenzent domagał się usilnie określenia, co autor rozumie przez „dogmatykę prawa". Na polskich uniwersytetach takie oczekiwania kierowane są zazwyczaj do studentów pierwszego roku przy okazji egzaminu ze wstępu do prawoznawstwa. Stan ten potwierdza również A. Peczenik, stwierdzając, że ,dogmatyka prawa w sensie europejskim nigdy tam [w krajach anglosaskich] nie istniała" - idem, Stan obecny teorii i filozofii prawa w krajach zachodnich, [w:] Studia z filozofii prawa, red. J. Stelmach, Kraków 2003, s. 11.

${ }^{3}$ G. Tellenbach, Church, State, and Christian Society at the Time of the Investiture Contest, London 1959, s. 164.

${ }^{4}$ R.W. Southern, Western Society and the Church in the Middle Ages, Harmonsdworth 1970, s. 34 .

5 Polskie wydanie: Prawo i rewolucja. Ksztaltowanie sie zachodniej tradycji prawnej, przeł. S. Amsterdamski, Warszawa 1995. Monografia ta wywoła debatę w środowisku polskich historyków i filozofów prawa — zob. „Państwo i Prawo” 12, 1996; J. Leszczyński, O pewnej (rewolucyjnej) hipotezie Harolda J. Bermana - prawo i nauka w średniowieczu, „Acta Universitatis Lodziensis. Folia Iuridica" 75, 2015. Odnotujmy, że Berman jest również autorem opracowania Law and Revolution II: The Impact of the Protestant Reformations on the Western Legal Tradition, Cambridge, MA 2003. 
zasad: wszędzie, gdzie było to możliwe, sprzeczności miały być rozstrzygnięte bez niszczenia elementów, które się na nie składały $[\ldots]^{6}$.

Wcześniejsza refleksja prawnicza oparta była głównie na analizie kazusów, na badaniu konfliktowych okoliczności rozpatrywanych z uwzględnieniem historii rozstrzygnięć prawnych ${ }^{7}$. Przełomowy charakter zmian, które dokonały się w następstwie przywołanych wydarzeń politycznych, polegał na przeniesieniu punktu ciężkości w poszukiwaniu podstawy rozstrzygnięć prawnych z argumentu opartego na „pamięci” o faktach (zwyczaj, precedens) na argument z „wiedzy” o zasadach i regułach prawnych. Jednostkowe zdarzenia z przeszłości zastąpione zostały ogólnymi standardami orzekania. Historia wydarzeń społecznych, w tym politycznych, oraz podjętych w takich lub innych okolicznościach rozstrzygnięć prawnych ,zasłonięta” zostaje bezkontekstową, ahistoryczną regułą zdolną spełniać funkcję ratio decidendi w nieokreślonej liczbie przypadków orzeczniczych podejmowanych w sprawach danego rodzaju. Przemiana ta stworzyła warunki do autonomii prawa i myśli prawniczej wobec otoczenia społecznego, w tym także wobec polityki. Tak oto $\mathrm{z}$ walki o władzę polityczną zrodziła się apolityczna myśl prawnicza. Reorientacja ta uruchomiła zapotrzebowanie na wiedzę prawniczą, którą zaspokoić mogła już tylko wyspecjalizowana grupa zawodowa. Tak powstał zawód prawnika w dzisiejszym jego rozumieniu. Rewolucja papieska stała się przez to „siłą napędową [...] europejskich uniwersytetów oraz kształtowania się jako samodzielnych dyscyplin teologii, prawoznawstwa i filozofii"”.

W opinii Harolda Bermana to wyszkoleni w prawie kanonicznym prawnicy nie pozwolili, by papież i cesarz zdobyli wobec siebie przewagę. Ich rolą stało się godzenie konfliktów pomiędzy stronami, a tym samym utrzymywanie systemu politycznego w równowadze. Dało to początek scholastyce, która stała się jednym ze znaków rozpoznawczych średniowiecznej filozofii. Tak i nie Piotra Abelarda, sztandarowe dzieło tego okresu, przedstawiać miało metodę godzenia zróżnicowanych kanonów. To średniowieczna uniwersytecka scholastyka przyczyniła się do zbudowania zrębów współczesnej dogmatyki prawa9 ${ }^{9}$ Tak zwany spór o uniwersalia (nominalizm-realizm) ukształtował tak ważną dla prawników zależność między tym, co ogólne (reguła) oraz indywidualne i konkretne (osoba, stan faktyczny). „Nominaliści uważali, że uniwersalne zasady są wytworem racjonalnego umysłu i woli - a zatem mogą być przez nie modyfikowane, że [zasady] odnoszą się do właściwości poszczególnych przedmiotów i że te mogą

${ }^{6}$ H.J. Berman, op. cit., s. 142-143.

7 Ibidem, s. 161, 182 i 183; zob. także H. Kupiszewski, Prawo rzymskie a współczesność, Warszawa 1988, s. 52.

${ }^{8}$ H.J. Berman, op. cit., s. 119. W stworzonej przez Irneriusa w 1087 roku w Bolonii szkole prawa w XII i XII wieku studiować miało od 1000 nawet do 10000 studentów z całej Europy Ibidem, s. 156 i 193.

9 „Dwunastowieczni prawnicy zajmowali się tym, co znacznie później nazwano dogmatyka prawa" - ibidem, s. 187. 
je potwierdzać lub obalać”. To ogólne zasady „rządzą” zatem faktami, a nie odwrotnie, jak wcześniej zakładano. Otworzyło to drogę argumentacji opartej na rozumowaniach logicznych. Nominalizm w wersji proponowanej przez Abelarda przyjmował jeszcze inne, przełomowe dla prawników twierdzenie: „całość zawarta jest w częściach”, „części rozpatrywane poza całością nie są takie same jak wówczas, gdy wiążą je wzajemne stosunki w ramach całości”. Nominalizm okazał się zatem ,szczególnie przydatny dla systematyzacji i syntetyzowania prawa"10. Ogólność reguły i ujmowanie zbiorów reguł w system to przecież kanon współczesnej analizy dogmatycznoprawnej.

Istotny dla ówczesnego przeobrażenia myśli prawniczej był również wpływ prawa rzymskiego, którego już wcześniej nauczano w Bolonii w oparciu o teksty zebrane przez Justyniana (Kodeks, Instytucje, Nowele i, przede wszystkim, Digesta). Jednak to dopiero dzięki profesorom uniwersytetu te kazuistyczne źródła zostały uporządkowanie i podane w formie jednolitego wykładu (Corpus Iuris Civilis). Fenomenem tamtych czasów było to, że ówczesna myśl uniwersytecka potrafiła - ze względu przede wszystkim na potrzebę spójności nauczania prawa — wykazać, że za ogromną ilością kazusów, szczegółów i niejasnych pojęć prawa rzymskiego udostępnionego w Justyniańskiej kompilacji „stał skomplikowany system pojęć abstrakcyjnych" ${ }^{11}$. Zachodnie uniwersytety w swoich dążeniach do konceptualizacji instytucji prawnych i systematyzacji prawa w spójny korpus wiedzy podniosły analizę prawa do poziomu nauki ${ }^{12}$. Oczywiście nie należy też zapominać o greckiej (Arystoteles) dialektyce i retoryce, wykorzystywanej przez prawników już w czasach rzymskich, a szeroko adoptowanej również przez średniowieczne szkoły prawa jako podstawy sztuki argumentowania i sądzenia.

Jak pointuje Harold Berman, ,rewolucja papieska zakończyła się kompromisem między starym i nowym światem [...]. Dzieci i wnukowie rewolucji przekształcili jej zasady w instytucje prawne [...]. Jej wyniki w mniejszym lub większym stopniu utrwaliły się na stulecia"13. Powstała europejska kultura prawna ${ }^{14}$. I, jak dodaje, ,nawet wielkie rewolucje narodowe przeszłości — rosyjska z 1917 r., francuska i amerykańska z 1789 i 1776, rosyjska z 1917 r. [...] ostatecznie godzily się $\mathrm{z}$ tą tradycją, nawet jeśli niektórzy z przywódców zamierzali ją zniszczyć” ${ }^{15}$. Nowe porządki prawne ustanawiane przez wielkie rewolucje oświeceniowe przekształcały

10 Ibidem, s. 175.

11 Ibidem, s. 161.

12 Ibidem, s. $176 \mathrm{n}$.

13 Ibidem, s. 132-133.

14 Autor wymienia 10 atrybutów zachodniej tradycji prawnej (ibidem, s. 21-24), jak również znamiona kryzysu współczesnego prawa (1983). Te ostatnie dostrzega w: 1. zaniku przekonania o uniwersalistycznym charakterze europejskiej kultury prawnej; 2. zrywaniu z indywidualizmem prawa na rzecz kolektywizmu (,,powrót do prawa szczepowego”), i 3. ataku na autonomię prawa i próby deprecjacji zawodu prawnika - ibidem, s. 51.

15 Ibidem, s. 19. 
zastaną tradycję prawną, mieszcząc się wszakże w jej ramach, polityczne przewroty i rewolucje nie zniszczyły jej, lecz ją odnawiały ${ }^{16}$.

\section{3.}

Historia prawa dostarcza nam innej jeszcze opowieści o powstaniu europejskiego prawoznawstwa w kontynentalnej nauce prawa w kształcie, w jakim obecnie go znamy. Historia ta czasowo jest nam bliższa, bo swoje najbardziej znaczące wydarzenia lokuje w XIX wieku i chyba z tego powodu bywa częściej przywoływana przez współczesnych teoretyków i dogmatyków prawa - głównie przez cywilistów. Jest tak, ponieważ jej uwieńczeniem stało się uchwalenie niemieckiego kodeksu cywilnego (BGB $)^{17}$. Nie to jednak wydaje się najważniejsze, a towarzyszące ówczesnej debacie doktrynalno-prawnej tło społeczne $\mathrm{z}$ równie silnym akcentem politycznym, jakim była presja na państwową integrację podzielonych w tamtym czasie Niemiec. I tym razem cel polityczny miał zostać osiągnięty ze znaczącym udziałem prawników. Tylko „logika” relacji między tym, co polityczne, i tym, co prawnicze, uległa odwróceniu: jeśli w wieku XI polityczny konflikt wyłonił niezaangażowaną naukę i praktykę prawniczą, to przypadek niemiecki pokazał, jak z radykalnego konfliktu prawnego może się wykształcić program osiągania podzielanego przez większość celu politycznego. To właśnie wpierane na tradycji romanistycznej dążenie do uniwersalności, jakości i wewnętrznej spójności prawa, głównie ustawodawstwa (projektowany BGB), okazało się bowiem skutecznym narzędziem osiągnięcia tego celu. Zwycięzcą doktrynalnym okazała się raz jeszcze tradycja prawa rzymskiego, która za swojego głównego przeciwnika miała i tym razem koncept ",prawa narodowego" (prawa zwyczajowego opartego na idei wspólnoty) ${ }^{18}$. Może zatem „opowieść”, którą pokrótce referuję w dalszej części tekstu, należałoby nie tyle nazywać „drugą”, co raczej „drugim etapem” tej sprzed 800 lat. Spajającą klamrą jest bez wątpienia podobne źródło (władza polityczna) i podobne następstwa w postaci impulsu, jaki wydarzenia polityczne nadały rozwojowi prawa, prawoznawstwa i praktyki prawniczej.

16 Ibidem, s. 24.

17 „Badając rozwój prawa w Niemczech, obserwujemy zjawiska, które wystąpiły w większości państw europejskich, tyle że z różną częstotliwością i siłą. Rozwój prawa na terenie Rzeszy był najbardziej podobny do dziejów prawa we Francji [...]. W obu państwach bowiem, z powodu rozdrobnienia dzielnicowego, mocno rozwijają się prawa lokalne (tak zwane zwyczaje) oraz - podobnie jak w całej Europie - następowało rozwarstwienie prawa [...]”. A. Ogurek, B. Olszewski, Dzieje niemieckiej myśli prawa cywilnego do końca XIX wieku, [w:] Prace z myśli polityczno-prawnej oraz prawa publicznego, red. M. Sadowski, P. Szymaniec, Wrocław 2012, s. 93.

18 H. Berman, charakteryzując prawo sprzed opisywanego przez siebie przełomu, jak również — co ciekawe - wskazując na źródła obecnego kryzysu europejskiej kultury prawnej (rok wydania monografii: 1983), używa takich określeń, jak: „,kolektywizm”, ,prawo szczepowe” czy „zintegrowana kultura szczepowa Germanów" — idem, op. cit., s. 51 i 617. 
Recepcja prawa rzymskiego w Niemczech rozpoczęła się znacznie wcześniej aniżeli przywoływane tu dziewiętnastowieczne wydarzenia polityczne. Jednak to wtedy nastąpiła kulminacja pewnego znaczącego procesu społeczno-politycznego i towarzyszącego mu sporu doktrynalno-prawnego. Ów proces polityczny podążał w dwóch niezależnych od siebie, rozbieżnych kierunkach: wspomnianej już presji na integrację państwową, budowaną pod znakiem „narodowej wspólnoty”, oraz ekspansji dyktowanej przez rewolucję przemysłową i kształtującą się wtedy nowoczesną gospodarkę rynkową, której znakiem rozpoznawczym były z kolei „własność i wolność jednostki”. Toczone wcześniej w doktrynie niemieckiej debaty między propagatorami prawa natury i tak zwanej szkoły historycznej ustąpiły w XIX stuleciu miejsca spektakularnym sporom w ramach już samej szkoły historycznej, doprowadzając do jej podziału na dwa obozy: „romanistów” i „germanistów”. Pierwszemu przewodził Karl F. von Savigny, drugiemu Friedrich K. Eichhorn. Savigny argumentował, że prawo ma przede wszystkim służyć obywatelom i prowadzić Prusy do kapitalizmu, czerpiąc z tradycji Corpus Iuris Civilis, a więc znanych nam już Justyniańskich źródeł prawa rzymskiego. Eichhorn z kolei nawoływał do odrodzenia prawa rdzennie niemieckiego, do podtrzymywania „wszystkich instytucji prawnych, które wywodziły się z rodzimych pierwiastków prawa" ${ }^{19}$. Jak piszą komentatorzy tych sporów:

walki germanistów z romanistami szybko przekroczyły ramy sporów teoretycznoprawnych [...]. Nienawiść do szkoły romanistycznej była tak dalece posunięta, że zwalczanie jej uważane było za akt świadomości narodowej, chroniący rodzime prawo przed wpływami obcymi. Jeszcze gorsze czasy nastały dla romanistów w latach 40. XIX wieku, kiedy to do zwalczania ich poglądów zwoływane były manifestacje ${ }^{20}$.

$\mathrm{Z}$ czasem spór nieco złagodniał, ale podziały ostały się na długie lata, odżywając nieprzypadkowo w latach trzydziestych XX wieku, kiedy to „germaniści” uzyskali dodatkowy impet za sprawą doktryny i praktyki opartej na idei narodowo-socjalistycznej.

Wróćmy jednak jeszcze do poprzedniego wieku. Savigny był sceptyczny co do sensowności uchwalenia jednolitej kodyfikacji niemieckiego prawa cywilnego, jednak nie dlatego, że uważał to przedsięwzięcie za niepotrzebne, ale ponieważ pokładał w idei kodyfikacji wysokie warsztatowe i jakościowe oczekiwania (pojęciowe, konstrukcyjne, mające prowadzić do prawodawczej spójności i decyzyjnej pewności). Ich spełnienie uważał za niemożliwe w niedojrzałej wtedy jeszcze - w jego ocenie - niemieckiej nauce prawa i praktyce legislacyjnej. Przywołując jako wzorcowy kontrprzykład ustabilizowaną władzę Rzymu i prawo rzymskie, Savigny argumentował, że w podzielonych politycznie państwach niemieckich, dotkniętych syndromem miejscowej specyfiki kulturowej, językowej, zmian społecznych

19 K. Grzybowski, O miejscu niemieckiej szkoty historycznej w rozwoju nauki prawa, „Czasopismo Prawno-Historyczne" 8, 1956, s. 341 n.

20 A. Ogurek, B. Olszewski, op. cit., s. 100-101. 
i ciągłej wędrówki ludzi (plemion germańskich), nie było warunków do zrównoważonego rozwoju prawa ${ }^{21}$. Podobnie rzecz miała się z jego oceną niemieckiej nauki prawa, słabo jeszcze ukształtowanej, uwikłanej w kulturowe rozbieżności, a tym samym pozbawionej prawniczego autorytetu o powszechnie uznanej pozycji a tylko na takiej osobie, jak uważał, może się opierać projekt aktu nowoczesnej legislacji ${ }^{22}$. Jak przystało na orędownika historycznej szkoły prawa, twierdził, że prawnikowi potrzebny jest nie tylko zmysł historyczny pozwalający mu na rozumienie perspektywy historycznej, w ramach której powstaje prawo, ale także zmysł systematyczny umożliwiający jakościowo dobre ustawodawstwo oraz późniejsze spójne stosowanie i interpretowanie uchwalonej ustawy ${ }^{23}$. Dodajmy jeszcze, interesujące w kontekście naszych rozważań, ujęcie przez Savigny’ego relacji miedzy tym, co polityczne i naukowe. Otóż „związek prawa z ogólnym życiem narodu” pozyskiwany przez „zmysł historyczny” autor nazywa „elementem politycznym”, a „wyspecjalizowany naukowy rozwój prawa jego elementem technicznym" ${ }^{24}$. Jego historyzm ma zatem niejako podwójny wymiar — to historyzm polityczny lokowany w, jak to określał, „,iedlisku prawa”, jakim jest opierana na historii wspólna świadomość narodu, oraz historyzm naukowy z prawem rzymskim w roli głównej, z jego „wyborną terminologią, która pozostaje w ścisłym związku z nauką"25.

Roszczenie do ujmowania ustawy jako wewnętrznie spójnego wytworu legislacji, a w konsekwencji tego również roszczenie do jednolitego rozumienia przez prawników tekstu takiej ustawy - a więc dobrze nam dzisiaj znane ujęcie prawa jako systemu - miało czytelną genezę historyczno-polityczną oraz istotne - ale już do pewnego stopnia zaskakujące — konsekwencje dla samej nauki prawa. Jak pisze John M. Kelly:

wezwanie do badań historycznych niemieckiego prawa doprowadziło do specyficznie germańskiej historycznej nauki prawa [...] intensywnej prawniczej archeologii w prawie rzymskim [...], odsiewania nie tylko średniowiecznych, ale także Justyniańskich nawarstwień i odsłaniania rzymskich reguł okresu klasycznego [...]. Z tego podejścia wyłoniła się koncepcja systemu — bardziej odpowiadająca tym niemieckim prawnikom, którzy chcieli wesprzeć zjednoczenie, także prawne, ich podzielonego politycznie kraju, bowiem prawo późnego rzymskiego imperium również nabrało cech systemu stosowanego w wielu regionach ${ }^{26}$.

Owych prawniczych archeologów zwykło się określać „,pandektystami”, jako że skupiali uwagę przede wszystkim na Digestach (łaciński źródłosłów greckiej nazwy Pandectae).

21 K.F. von Savigny, O powołaniu naszych czasów do ustawodawstwa i nauki prawa, Warszawa 1964, s. 76.

22 Ibidem, s. 167-168.

23 Ibidem, s. 83.

24 Ibidem, s. 57.

25 Ibidem, s. 56 i 70.

26 J.M. Kelly, Historia zachodniej teorii prawa, Kraków 2006, s. 351-352. 
W ten oto sposób dziewiętnastowieczny rozwój niemieckiej kultury prawnej doprowadził do powstania szkoły teoretyków prawa, których dzieło doprowadziło do pozytywizmu prawniczego ${ }^{27} \mathrm{z}$ dogmatyką prawa w roli dominującej, ze wszystkim dzisiaj dobrze nam znanymi atrybutami i słabościami tego nurtu (siatka autonomicznych pojęć prawniczych, metoda formalno-dogmatyczna, interpretacyjny formalizm, aksjologiczna, w tym polityczna neutralność nauki, ale też logiczna operacjonalizacja rozstrzygnięć orzeczniczych, sędziowska niezależność itp.). Po raz drugi na politycznym gruncie wyrosła, a na pewno znacząco się umocniła, apolityczna nauka prawa z dopasowaną do niej dydaktyką akademicką i odpowiednio ukształtowanymi postawami sędziowskimi i orzecznictwem. Ewolucja ta - bo termin „rewolucja” należałoby chyba jednak za Bermanem zarezerwować dla wydarzeń z XI wieku — była zresztą zjawiskiem szerszym, wykraczającym poza krąg niemieckiej kultury prawnej ${ }^{28}$. Uwieńczeniem tego procesu było wejście w życie, z (skądinąd symboliczną) datą 1 stycznia 1900 roku, niemieckiego kodeksu cywilnego - ustawy z nielicznymi zmianami obowiązującej do dnia dzisiejszego. BGB ma zatem za sobą niełatwą, jednak zasadniczo udaną (przynajmniej w sensie zdolności przetrwania) próbę konfrontacji z najgroźniejszym bodaj spośród dwudziestowiecznych totalitaryzmów. Do niechlubnej listy Bermana „rewolucji narodowych przeszłości”, które usiłowały „nawet zniszczyć” europejską kulturę prawną można zatem dodać również „rewolucję" niemiecką z lat trzydziestych, a niemiecki BGB jako dowód, że ówczesna presja polityczna nawet jeśli nie wpłynęła na - używając słów Bermana — „odnowienie” tej przełomowej dla europejskiej kultury prawnej ustawy, to przynajmniej jej „nie zniszczyła”29.

\section{4.}

Zintegrowana z pozytywizmem prawniczym kontynentalna teoria i dogmatyka prawa miały się w Europie w latach następnych (pomimo zrozumiałych różnic i napięć) całkiem dobrze. Dotyczy to przede wszystkim dogmatyki prawa. Sprawy zaszły nawet dalej. W latach osiemdziesiątych ubiegłego wieku pojawia

27 Ibidem, s. 351.

${ }^{28}$ Zbliżony, choć uwikłany oczywiście w swój lokalny kontekst historyczno-polityczny, proces Kelly odnotowuje również we Francji: „za przyczyną paradoksalnej ewolucji kultura prawna Francji zrazu zaproponowała objawienie doskonałości rozumu w nowym Kodeksie cywilnym, będący ostatnim słowem tradycji prawa natury, by skończyć na skrajnym pozytywizmie zwracającym uwagę na słowa i wolę prawodawcy jako jedyną podstawę zasadności prawa”. Ibidem.

29 Natomiast nieco inaczej potoczyły się losy niemieckiej powojennej teorii prawa. Polityczna neutralność przekształciła się w zarzut obojętności, a nawet stwarzania warunków sprzyjających „prawnym” praktykom władz faszystowskich. Konsternacja prawniczych pozytywistów spowodowała, że teoria prawa w Niemczech została — jak ujął to A. Peczenik — „skolonizowana przez filozofię prawa Habermasa i socjologię Luhmanna. Ani jedna, ani druga nie wyrosła z potrzeb prawnika. Przyszły z zewnątrz”. A. Peczenik, op. cit., s. 10. 
się — za sprawą głównie Auliusa Aarnio, a życzliwie przyjęty również w polskiej literaturze teoretycznej — zapożyczony z metodologii przyrodoznawczej koncept „paradygmatu dogmatyki prawa" ${ }^{30}$. W swoim źródłowym ujęciu (Thomas Kuhn) ów paradygmat miał obejmować środowiskowo akceptowany zestaw pojęć i teorii tworzących podstawy określonej nauki, otwierających drogę do rozwiązywania bardziej szczegółowych problemów badawczych podejmowanych $\mathrm{w}$ danej dyscyplinie. Odwołanie się do koncepcji paradygmatu - występującego później u Aarnio pod nazwą ,matrycy interpretacyjnej” — wyrażać miało stabilność zastanych sposobów rozwiązywania przez dogmatykę prawa stawianych przed nią problemów badawczych, a ze względu na społeczną funkcję dogmatyki, również problemów praktycznych ${ }^{31}$. Jak ujmował to Aarnio, prawnicy, urzędnicy, a także obywatele potrzebują wiedzy o treści regulacji prawnych, a taka potrzeba może być zaspokajana tylko przez badania dogmatycznoprawne — to oznacza, że przede wszystkim z powodów społecznych ,podstawowa matryca dogmatyka prawa jest stabilna"32. Zdaniem przywoływanego autora nie jest zatem uzasadnione oczekiwanie na zmiany paradygmatu dogmatyki prawa. Obserwowane zmiany, jeżeli już mają się dokonywać, to raczej wewnątrz podstawowej matrycy dyscyplinarnej, która jest interpretowana stosownie do zmieniających się społecznych oczekiwań. Natomiast zmiana zewnętrzna oznaczałaby de facto likwidację dogmatyki prawa, zastąpienie jej na przykład przez empiryczną socjologię ${ }^{33}$.

Istotne dla omawianej problematyki jest to, że oczekiwanie stabilności standardów służących rozwiązywaniu kwestii społecznych pojawia się również po stronie współczesnych badaczy zajmujących się teorią (filozofią) polityki, jakkolwiek język, a tym samym pojęciowa klarowność tego postulatu jest daleko mniejsza aniżeli zazwyczaj u prawników. Na przykład Chantal Mouffe, jedna z najbardziej obecnie wpływowych lewicowych badaczek teorii demokracji - co interesujące, zwolenniczka inspirowanego poglądami Carla Schmitta społecznego podziału na „wrogów” i „przyjaciół” — widzi potrzebę istnienia mechanizmów stabilizujących z zewnątrz konflikty pomiędzy politycznymi „wrogami”.

30 A. Aarnio, On paradigm of legal dogmatics: Problems of scientific progress in legal research, [w:] Contemporary Conceptions of Law: Proceedings of the 9th World Congress, Basel 27.8.1979-1.9.1979, red. P. Trappe, Wiesbaden 1982; idem, Paradigms in legal dogmatics, [w:] Theory of Legal Science, red. A. Peczenik, Dordrecht 1984; idem, Reason and Authority. A Treatise on Dynamic Paradigm of Legal Dogmatics, Aldershot 1997; J. Wróblewski, Paradygmat dogmatyki prawa a prawoznawstwo, [w:] Szkice z teorii prawa i szczegółowych nauk prawnych, red. S. Wronkowska, M. Zieliński, Poznań 1990; J. Leszczyński, O niezmienności sposobu uprawiania dogmatyki prawa, „Studia Prawno-Ekonomiczne” 81, 2010.

31 J. Leszczyński, interpretując poglądy A. Aarnio, zauważa, że ,niepowodzenia w zrekonstruowaniu zmian paradygmatu dogmatyki prawa spowodowane są tym, że dogmatyka prawa nie jest jedynie [...] dziedziną poznania, [ale] co najmniej w równym stopniu sferą działania praktycznego". Idem, O niezmienności sposobu..., s. 125.

32 A. Aarnio, Reason and Authority..., s. 252.

33 Ibidem. 
Jak pisze, „najważniejszym zadaniem nowoczesnej demokratycznej polityki jest transformacja antagonizmu w agonizm”, a ,celem polityki demokratycznej [...] powinno być stworzenie ogólnej ramy, dzięki której konflikty mogłyby przyjmować formę agonistycznej konfrontacji przeciwników, zamiast przejawiać się jako antagonistyczna walka wrogów"34. Autorka nie pisze wprost o prawie jako składniku instytucji demokratycznych i potencjalnej płaszczyźnie konfrontacji politycznych przeciwników. Być może ma je na myśli, a jeżeli nie, to warto by jej podpowiedzieć, że takie ufundowane na zrębach dogmatyki prawa, użyteczne dla demokratycznej polityki medium już od czasów rzymskich istnieje — przynajmniej gdy chodzi o materię prawa prywatnego $-\mathrm{z}$ kontradyktoryjną rozprawą sądową jako techniką organizacji i realizacji społecznych konfliktów. A skoro medium to ma za sobą udane konfrontacje $\mathrm{z}$ rozlicznymi wydarzeniami i konfliktami politycznymi przeszłości (i poddawane było weryfikacji pod wpływem takich wydarzeń), to może również współcześnie, w czasach tak zwanej późnej nowoczesności, będzie zdolne wypełniać takie zadanie. Warto przynajmniej spróbować. Aby jednak miało szansę tak się stać, nie wystarczą apele kierowane do badaczy nowoczesnej demokracji. Niezbędne wydaje się dokonanie pewnych adaptacyjnych zmian - a więc z zachowaniem rdzenia wypracowanego przez dogmatykę paradygmatu — również po stronie nauki prawa i praktyki sądowej. Dwie uwagi pod adresem prawa i prawników wydają się tu być szczególnie istotne.

Dogmatyka prawa i sądownictwo powinny mocniej kooperować z otoczeniem społecznym i otwierać się na zachodzące w nim zmiany technologiczne i kulturowe, w tym również polityczne. Postulat tego rodzaju badawczej otwartości i idące w ślad za nim oczekiwanie sędziowskiej wrażliwości nie są czymś nowym w nauce prawa, a przynajmniej w teorii prawa uprawianej w perspektywie problemowo obejmującej dogmatykę prawa i praktykę prawniczą. Badanie wielopłaszczyznowe, zastąpione w nowszej literaturze postulatem zewnętrznej integracji prawoznawstwa, to już niemal kanon rozprawiania w metodologii nauk prawnych. Rzecz zatem w jego realizacji w prawniczych „naukach szczegółowych” — tak nazywanych przez Zygmunta Ziembińskiego właśnie dlatego, aby podkreślić, że typowa problematyka dogmatyczno-prawna nie jest, a na pewno nie powinna być jedyną jaką zajmują się dziedzinowo wyspecjalizowane nauki prawne. Te „niedogmatyczne” segmenty budujące wiedzę i oceny prawnika przy rozwiązywaniu tradycyjnych problemów dogmatyczno-prawnych powinny ulegać zmianom pod wpływem impulsów docierających z społecznego otoczenia. Wyzwaniem nie jest zatem sam paradygmat dogmatyki prawa, ale potrzeba uwzględniania $\mathrm{w}$ jego ramach zmieniającej się wiedzy i ocen pochodzących ze środowiska społecznego ${ }^{35}$. Wymagać to będzie odpowiednich zmian w akade-

${ }^{34}$ Ch. Mouffe, Polityka bez przeciwnika, [w:] Paradoks demokracji, przeł. W. Jach, Wrocław 2005, s. 133.

35 Ziembiński pisze o „pozornej prostocie paradygmatu dogmatyki prawniczej”, który bierze się z „symplicyzującego obrazu dogmatyki jako realizującej swoje zadania poprzez zalgorytmizo- 
mickiej i zawodowej edukacji prawniczej, zmierzających w stronę pogłębienia integracji obecnych programów nauczania z naukami społecznymi (historia, politologia, filozofia, socjologia, teoria kultury, itp.), co pozwoli rozszerzać horyzonty prawniczego postrzegania rzeczywistości. Jedynie wtedy dogmatyka prawa i orzecznictwo będą mogły nie tylko ,przekształcać się" i ,odnawiać” pod wpływem ,politycznych przewrotów” i „,rewolucji”, ale zdolne będą antycypować takie lub podobne wydarzenia i neutralizować je swoimi decyzjami. Profesorowie prawa, studenci i sędziowie powinni zatem z pożytkiem dla siebie — a przede wszystkim pełnionej roli społecznej — czytać również Schmitta czy Mouffe z ich politycznymi dystynkcjami na „wrogów” i „przyjaciół”. Mogą bowiem znaleźć się w towarzystwie tak identyfikowanych oponentów w salach wykładowych czy w salach rozpraw.

I jeszcze druga uwaga. Współczesne filozofie polityki, a wespół z nimi środowiska realnej polityki - z których płynie obecnie szczególnie ostra krytyka prawoznawstwa i sądownictwa - są zróżnicowane. Niebezpiecznie łączy je jednak fenomen politycznego radykalizmu, zarówno lewicowego (vide: nurt critical legal studies), jak i prawicowego (na przykład inspirowany Schmittem program political theology). Nurty te podobnie pozycjonują politycznego „wroga”, za jakiego uważają instytucje liberalnej demokracji, w tym naukę prawa i sądownictwo jako jej istotne części składowe. Przywołane wcześniej wydarzenia polityczne z XI i XIX wieku przebiegały i konstruktywnie kończyły się z doniosłym udziałem prawa i prawników. Obecnie jednak to sami prawoznawcy i instytucje, w ramach których działają (uniwersytety, sądy), stały się „wrogiem” przywołanych nurtów filozofii politycznej. To istotna różnica. Prawoznawcom i sądowym decydentom należałoby w tej sytuacji zalecić postawę rozsądku, miarkowanej w duchu antycznego fronesis otwartości na światopoglądowe zamiany dyktowane przez filozofów polityki. Podejście takie zawsze miało w sobie walory uniwersalizujące i, przede wszystkim, tonujące atmosferę sporu politycznego. To jednak może nie wystarczyć. Akademicy i sędziowie powinni również podjąć wysiłek i skonfrontować zastany paradygmat swojej zawodowej dyscypliny/dziedziny z pewnymi istotnymi dla współczesnej filozofii politycznej roszczeniami.

Wrocławski filozof polityki Leszek Koczanowicz w ramach proponowanej przez siebie koncepcji tak zwanej niekonsensualnej demokracji stwierdza, że dialog społeczny nie ma już prowadzić do porozumienia. Jego wartość polegać ma natomiast na szansie, jaką stwarza dla lepszego rozumienia się stron

wane wykonywanie reguł [...]”. I dodaje: jakkolwiek ,terminologia i aparatura pojęciowa prawa, niektóre podstawowe konstrukcje myślowe, zarysy ogólne niektórych instytucji prawnych dziedziczone są z formacji na formację [...] [to jednak] w toku tej sukcesji ulegają [...] zmianom”. Dlatego powstaje potrzeba uwzględniania „odmiennej wiedzy o sprawach społecznych” i „odmiennego systemu ocen [...]”. „Różnica leży w przyjmowanych systemach wartości, a nie w samym przez się paradygmacie metodologicznym rozstrzygania problemów dogmatycznych". Idem, Szkice z metodologii szczegółowych nauk prawnych, Warszawa 1983, s. 73, 87). 
sporu $^{36}$. Wiąże się to $\mathrm{z}$ nieusuwalną naturą antagonizmów społecznych współczesnej praktyki demokratycznej. Odnosząc twierdzenie powyższe do interesującej nas problematyki, w niekonsensualnej demokracji proces prawny, ma być forum ekspresji pluralistycznych wartości, „medium umożliwiając[ym] poprawę rozumienia, a nie sposób dochodzenia do konsensu [...] czy [tym bardziej] rozstrzygani[a] sporów"37. Mamy zatem ważne rozwinięcie przywołanej wcześniej tezy Mouffe. Sala sądowa powinna stać się miejscem, które pozwoli przekształcić nieusuwalny społeczny antagonizm pomiędzy wrogami w relację agonistyczną między przeciwnikami — jak nazywa to belgijska filozofka demokracji — „,w paradoksalny sposób określanymi jako »przyjaźni wrogowie«, a zatem jako osoby będące przyjaciółmi, bowiem dzielą wspólną symboliczną przestrzeń, lecz które są również wrogami, gdyż chcą ja organizować inaczej"38.

W cytacie tym znajdujemy dwie wiadomości dla prawnika: dobrą, jaką jest użyteczność, a nawet szacunek do wspólnej przestrzeni, jaką może stwarzać sąd (prawo, proces prawny), oraz złą — dla sporów politycznych sąd nie jest miejscem porozumienia, a tym bardziej władczego rozstrzygania sporów, lecz jedną z wielu płaszczyzn politycznej ekspresji. Jednak i ta zła wiadomość ma dla prawnika wartość: (i) edukacyjną, gdyż uświadamia mu istnienie i wagę konfliktów politycznych, konfrontuje dotychczasowe pojmowanie jego roli zawodowej z politycznością — z różnymi, w tym politycznymi, motywacjami uczestników sporów sądowych oraz z takimiż skutkami ewentualnych sądowych rozstrzygnięć; oraz (ii) praktyczną (pragmalingwistyczną), ponieważ daje prawnikowi świadomość odmiennych idiomów, w ramach których działają politycy i prawnicy, uczestniczenia każdego $\mathrm{z}$ tych środowisk w innej - jak nazywał to Ludwig Wittgenstein — ,grze językowej”, grze w inny sposób racjonalizowanej i inaczej organizowanej. Dla polityka będzie to pragmatyczna orientacja na samo działanie (co nazywane bywa niekiedy ,postpolityką”). Dla prawnika jest to apragmatyczna orientacja na rezultat, z rozstrzygającym spór wyrokiem w funkcji wiodącej. A jeśli tak, to - podobnie jak skonfliktowani politycy również profesorowie prawa i sędziowie mają „prawo" do tego, aby „symboliczna przestrzeń”, jaką stwarza prawo, była „organizowana inaczej” niż to sobie wyobrażają teoretycy polityki i politycy. To nie może się zmienić, jeżeli oczywiście chcemy zachować dotychczasowe role społeczne dogmatyki prawa, sądów i urzędów. Gdyby zmiany zaszły, byłaby to rewolucja polityczna o skutkach dla kultury prawnej daleko wykraczających poza przywołane w niniejszym tekście wydarzenia z XI i XIX wieku.

36 L. Koczanowicz, Polityka dialogu, Warszawa 2015.

37 Ibidem, s. 197.

38 Zob. Ch. Mouffe, op. cit., s. 33. 


\section{Bibliografia}

Aarnio A., On paradigm of legal dogmatics: Problems of scientific progress in legal research, [w:] Contemporary Conceptions of Law: Proceedings of the 9th World Congress, Basel 27.8.19791.9.1979, red. P. Trappe, Wiesbaden 1982.

Aarnio A., Paradigms in legal dogmatics, [w:] Theory of Legal Science, red. A. Peczenik, Dordrecht 1984.

Aarnio A. Reason and Authority. A Treatise on Dynamic Paradigm of Legal Dogmatics, Aldershot 1997.

Berman H.J., Law and Revolution II: The Impact of the Protestant Reformations on the Western Legal Tradition, Cambridge, MA 2003.

Berman H.J., Prawo i rewolucja. Ksztattowanie się zachodniej tradycji prawnej, przeł. S. Amsterdamski, Warszawa 1995.

Grzybowski K., O miejscu niemieckiej szkoty historycznej w rozwoju nauki prawa, „Czasopismo Prawno-Historyczne" 8, 1956.

Kantor-Kozdrowicki P., Racjonalność prawodawcy jako paradygmat nauk prawnych, „Folia Iuridica Universitatis Wratislaviensis" 7, 2018, nr 1 .

Kelly J.M., Historia zachodniej teorii prawa, Kraków 2006.

Koczanowicz L., Polityka dialogu, Warszawa 2015.

Kupiszewski H, Prawo rzymskie a współczesność, Warszawa 1988.

Leszczyński J., O niezmienności sposobu uprawiania dogmatyki prawa, „Studia Prawno-Ekonomiczne" 81, 2010.

Leszczyński J., O pewnej (rewolucyjnej) hipotezie Harolda J. Bermana - prawo i nauka w średniowieczu, „Acta Universitatis Lodziensis. Folia Iuridica” 75, 2015.

Mouffe Ch., Polityka bez przeciwnika, [w:] Paradoks demokracji, przeł. W. Jach, Wrocław 2005.

Nowak L., Spór o definicje legalne a sposób „,pojmowania prawodawcy”, „Państwo i Prawo” 1969, nr 3.

Ogurek A., Olszewski B., Dzieje niemieckiej myśli prawa cywilnego do końca XIX wieku, [w:] Prace z myśli polityczno-prawnej oraz prawa publicznego, red. M. Sadowski, P. Szymaniec, Wrocław 2012.

Peczenik A., Stan obecny teorii i filozofii prawa w krajach zachodnich, [w:] Studia z filozofii prawa, red. J. Stelmach, Kraków 2003.

Savigny K.F., O powołaniu naszych czasów do ustawodawstwa i nauki prawa, Warszawa 1964.

Southern R.W., Western Society and the Church in the Middle Ages, Harmonsdworth 1970.

Tellenbach G., Church, State, and Christian Society at the Time of the Investiture Contest, London 1959.

Wróblewski J, Paradygmat dogmatyki prawa a prawoznawstwo, [w:] Szkice z teorii prawa i szczegółowych nauk prawnych, red. S. Wronkowska, M. Zieliński, Poznań 1990.

Zieliński M., Wyktadnia prawa. Zasady. Reguły. Wskazówki, Warszawa 2002.

Ziembiński Z., Problemy podstawowe prawoznawstwa, Warszawa 1980.

Ziembiński Z., Szkice z metodologii szczegółowych nauk prawnych, Warszawa 1983.

Zirk-Sadowski M, Prawo a uczestniczenie w kulturze, Łódź 1998.

Studia nad Autorytaryzmem i Totalitaryzmem 43, nr 2, 2021

(C) for this edition by CNS 